\title{
Validation of a method employing liquid chromatography to identify and quantify glycomacropeptide of casein in raw milk.
}

\author{
Validación de un método mediante cromatografía líquida \\ para identificar y cuantificar glicomacropéptido de caseína \\ en la leche cruda.
}

Fernando Murcia, Orlando Bernal², Olga Ávila³, Jenifer Guzmán4, Willinton Arias ${ }^{5}$, María Morales ${ }^{6}$.

JOURNAL VITAE

School of Pharmaceutical and Food Sciences

ISSN 0121-4004 | ISSNe 2145-2660 University of Antioquia Medellin, Colombia

Filliations

1 Director técnico consorcio consultoría PTP, Biotrends laboratorios SAS, R y G Asesorías S.A.S, Bogotá Colombia.

${ }^{2}$ Analista químico senior consorcio consultoría PTP, Biotrends laboratorios SAS, R y G Asesorías S.A.S, Bogotá Colombia.

3 Jefe de laboratorio consorcio consultoría PTP, Biotrends laboratorios SAS, R y G Asesorías S.A.S, Bogotá Colombia.

${ }^{4}$ Profesional senior vicepresidencia de agroindustria Colombia Productiva cuya vocera y administradora es la Fiduciaria Colombiana de Comercio Exterior Fiducoldex S.A Bogotá Colombia.

${ }^{5}$ Gerente general R y G Asesorías S.A.S Bogotá Colombia.

${ }^{6}$ Gerente de proyectos R y G Asesorías S.A.S, Bogotá Colombia.

*Corresponding Orlando Bernal obernalc@unal.edu.co

Received: 20 de February 2021 Accepted: 16 June 2021 Published: 11 August 2021

\begin{abstract}
Background: The information on official testing methods, or regulatory methods in Colombia to test whey in milk is limited; this restriction of information goes against the possibility of mitigating the risk of food fraud. Objectives: The validation of an HPLC method to determine casein glycomacropeptide (c-GMP), a protein that countries such as Brazil, Spain, and Ecuador have used as an indicator of raw milk adulteration with whey, was carried out. Methods: A $10 \mathrm{~mL}$ sample of raw milk is precipitated with $24 \%$ TCA using ultrasound, a process followed by filtration. The collected fraction ensured the separation of c-GMP and then injected into the liquid chromatography. Results: A 30 minutes analysis allowed the determination of c-GMP with a retention time of $12.9 \pm 0.5$ minutes. The performance characteristics method in the validation exercise were: recovery percentage $99.97 \%$, linearity $\mathrm{R}^{2}>0.95 ; \%$ RSD accuracy $<5.3 \%$. Conclusion, the method exhibits desirable attributes for the intended purpose.
\end{abstract}

Keywords: Casein glycomacropeptide c-GMP, High Pressure Liquid Cromatographic, whey milk, fraud food, raw bovine milk.

\section{RESUMEN}

Antecedentes: En Colombia la información de dominio público en metodologías de análisis de lactosuero en leche es limitada, restringiendo la posibilidad de acceder a ellas para mitigar el riesgo de fraude alimentario. Objetivos: Se realizó validación de un método por HPLC para determinar en leche cruda c-GMP, proteína usada como indicador de adulteración en países como Brasil y Ecuador. Metodos: Una muestra de $10 \mathrm{~mL}$ de leche cruda es precipitada con TCA al 24\% empleando ultrasonido, proceso seguido por filtración. La fracción recolectada aseguró la separación del c-GMP para luego inyectar al cromatógrafo líquido. Resultados: La determinación de c-GMP permitió el análisis en 30 minutos con tiempo de retención de 12,9 \pm 0,5 minutos. Las características de desempeño del método en el ejercicio de validación fueron: porcentaje de recuperación 99,97\%, linealidad $\mathrm{R}^{2}>0,95$; precisión \%RSD $<5,3 \%$. Conclusión: el método al final del ejercicio exhibe atributos para el fin previsto.

Palabras claves: Glicomacropéptido de caseína c-GMP, Cromatografía liquida de alta eficacia, lactosuero, fraude alimentario, leche cruda de bovino. 


\section{INTRODUCTION}

The Colombian dairy chain is currently facing important regulatory good agricultural practices (GAP's) problems that hinder the control of unauthorized practices, such as milk adulteration by whey addition. The mentioned conduct promotes unfair competition that leads to differences in the quality of the product and price fluctuations (1). This is why it is necessary to regulate the technical specifications of milk concerning the addition of whey and establish effective measurement methods.

Adulteration in milk production includes water, salt, glucose (or other sugar), urea, $\mathrm{pH}$ adjusters, melamine, malto-dextrose, whey (from the cheesemaking), and other substances added to correct the protein amount and/or density values. Considering the whey is a by-product of cheese production, adulteration of milk with this substance can be recognized as an attractive solution (2).

Decree 616 of 2006 establishes the requirements that milk must-have for human consumption, which is obtained, processed, packaged, transported, marketed, sold, imported, or exported in Colombia. In addition, chapter IV, Article 14 indicates explicitly the prohibition of adding whey to milk at any stage of the production chain and the commercialization in the national territory of products intended for human consumption with the name "milk", when they present modifications in its natural composition or the addition of unauthorized substances such as whey milk (3). However, it does not establish limits, quantities, or concentrations of whey that allow establishing the adulteration of milk.

Within the last years, the possible addition of whey as an adulterant in milk, mainly used to increase the product's volume to get economic gain has been a source of controversy (4). As whey is a natural component of milk, and due to its colligative properties, it mixes easily with it and cannot be accurately differentiated with basic control tests (5). The said use has several drawbacks; among the main ones is the fact that the whey production characteristics are not known, thus compromising the microbiological and hygienic quality of the product. Furthermore, its sanitization is not ensured, the technological properties of whey proteins do not allow the same yields in obtaining dairy products, promote unfair competition in prices and ultimately deceive the consumer by not being a product according to the definition of milk in Decree 616.
Whey protein composition indicates a heterogeneous mixture of different individual proteins, with their specific functional and physiological characteristics (6)their health benefits and current applications in functional foods and nutritional supplements. Whey proteins, once considered waste from cheese manufacture, have proven to be a source of bioactive components, and when used in functional foods can potentially lead to prevention of lifestyle diseases. Whey proteins represent about $20 \%$ of the total protein in bovine milk and are mostly made up of $\beta$-lactoglobulin ( $\beta$ Lg. Whey proteins are a mixture of different individual whey proteins, which are $\beta$-lactoglobulin (Molecular mass 18,3 kDa), $\alpha$-lactalbumin $(14,0$ $\mathrm{kDa})$, immunoglobulins (150 - $1000 \mathrm{kDa}$ ), bovine serum albumin $(66,0 \mathrm{kDa})$, lactoferrin $(76,5 \mathrm{kDa})$, lactoperoxidase $(78,0 \mathrm{kDa})$, protease-peptone (4 - $22 \mathrm{kDa})$ and glycomacropeptide (GMP) (6,8 kDa). Excluding glycomacropeptide, all other protein components are naturally present in whey, while glycomacropeptide is produced from casein during the first step of enzymatic cheese processing (7).

The casein glycomacropeptide (CMP or c-GMP) is a protein obtained as a soluble form in whey, corresponding to $15-20 \%$ of whey proteins (6). It is a hydrophilic peptide (contains about 102-169 amino acid residues) of kappa-casein that provides stability to casein micelles in milk; It is produced by the action of rennet on kappa-casein during the production of whey. c-GMP is unique within soluble serum proteins; its structure has an oligosaccharide attached to the peptide chain and a significant contribution of phenylalanine, tryptophan, and serine. In addition, it also has high levels of branchedchain amino acids such as leucine, isoleucine, and valine (8). Those are the main reasons why various authors suggest c-GMP as a marker and indicator of whey addition in milk, and the analytical methods have been based on determining the concentration of this protein (9). Consequently, methods such as gel electrophoresis (SDS-PAGE) and high-efficiency liquid chromatography (HPLC) stand out.

SDS-PAGE is a routine electrophoretic technique used to determine the molecular weight of individual proteins and peptides. However, many researchers have documented problems during the SDS-PAGE of GMP, especially during staining, as GMP does not stain appropriately with coomassie brilliant blue (CBB) (8).

When whey is added to the milk, it does not necessarily correct the proteins or $\mathrm{pH}$ since the 
matrix has the same origin. Thus, one way to detect this fraud is by using c-GMP as a marker because it is proportional to whey addition in milk. Olieman et al. (10). Proposed for the first time the use of c-GMP to detect frauds by whey addition in milk (1). The authors proposed selective milk's proteins precipitation with trichloroacetic acid (TCA) to obtain only c-GMP in the final acid extract. The separation and identification of c-GMP were performed using a Size-Exclusion Chromatography (SEC) method, with UV detection (205nm) (1).

The currently well-accepted method for detecting whey in milk is based on the detection and quantification of glycomacropeptide protein (GMP) by HPLC (1). Therefore, implementing the high-efficiency chromatography technique for the determination of c-GMP is relevant to identifying the protein within raw milk, considering a fraction is released by natural processes related to the bacterial activity (11) or by enzymatic processes triggered by practices associated with handling and storage.

Thus, this study aimed to evaluate the potential of HPLC as an effective, sensitive, reproducible, accurate, applicable, rapid, and non-destructive technique for the quantitative detection of whey milk with adulterant in samples of raw milk via the measurement of the presence of GMP, using highefficiency liquid chromatography. The reference method used for this analysis was based on the official physicochemical analytical method of Brazil published in Normative Instruction $N^{\circ} 68$ of 2006 "CMP Index" (12).

\section{MATERIALS AND METHODS}

\subsection{Reagents}

The reagents used in the analytical determination were trichloroacetic acid (TCA), potassium dihydrogen phosphate $\left(\mathrm{KH}_{2} \mathrm{PO}_{4}\right)$, dipotassium phosphate $\left(\mathrm{K}_{2} \mathrm{HPO}_{4}\right)$, anhydrous sodium sulfate $\left(\mathrm{Na}_{2} \mathrm{SO}_{4}\right)$ with purity not less than $98 \%$. Additionally, type 1 grade water was used for HPLC, Lacprodan protein concentrate (13) (fig. 1) was used as casein glycomacropeptide (c-GMP) standard with the following information: Lot 4J1493, brand Davisco Foods, Arla Foods, whose certificate of analysis indicates purity $76 \%$.

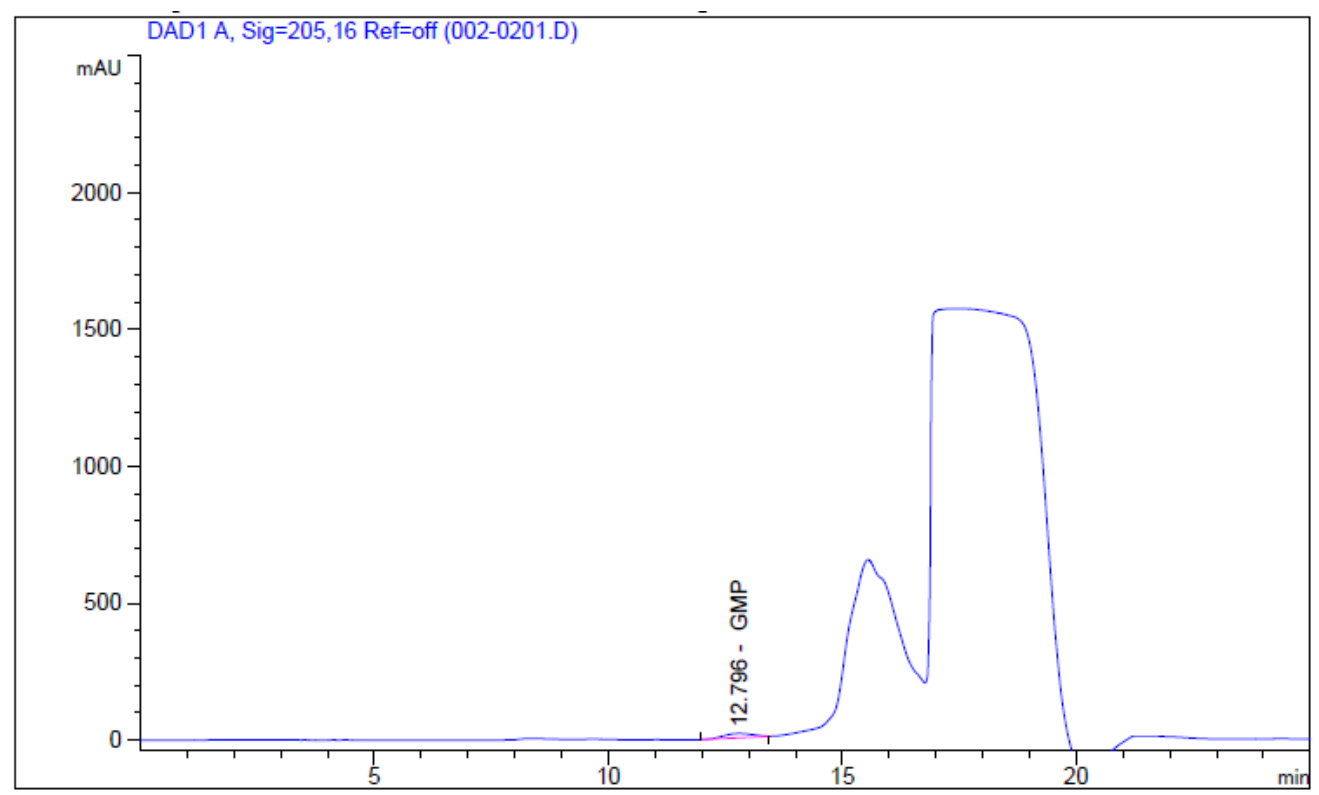

Figure 1. Typical chromatogram of the Lacprodan standard used in the quantification of c-GMP. The molecule of interest is marked with the response time. The signals that were not integrated correspond to trichloroacetic acid.

\subsection{Taking samples for analysis}

Each sample was taken from a fresh and recently milked milk canteen, using sterile packaging and subsequent conservation with $0.2 \%$ hydrogen peroxide; once collected, the sample was ensured under refrigeration $\left(4^{\circ} \mathrm{C}+/-2^{\circ} \mathrm{C}\right)$ until its transfer and arrival to Biotrends Laboratorios SAS facilities, where the tests were developed. 


\subsection{Precipitation method}

The refrigerated milk was conditioned by submerging the sample in a water bath at $30^{\circ} \mathrm{C}$ for 10 minutes, occasionally shaking the container (inverting 5 or 6 times gently). $10.0 \mathrm{~mL}$ of conditioned milk were weighed in $50 \mathrm{~mL}$ tube capacity; later, $5 \mathrm{~mL}$ of $24 \%$ TCA were added to the tube containing the milk. The mixture was sonicated for 20 minutes in an ultrasonic
Branson model 1510 with a maximum input power from 130W. After this time, filtration was carried out through quantitative filter paper (Munktell filter discs grade 389 , pore size $11 \mu \mathrm{m}$ ) and $3 \mathrm{~mL}$ of filtered liquid sample collected, then a sufficient quantity was transferred to a vial for direct injection to the HPLC and subsequent quantification (Fig. 2).

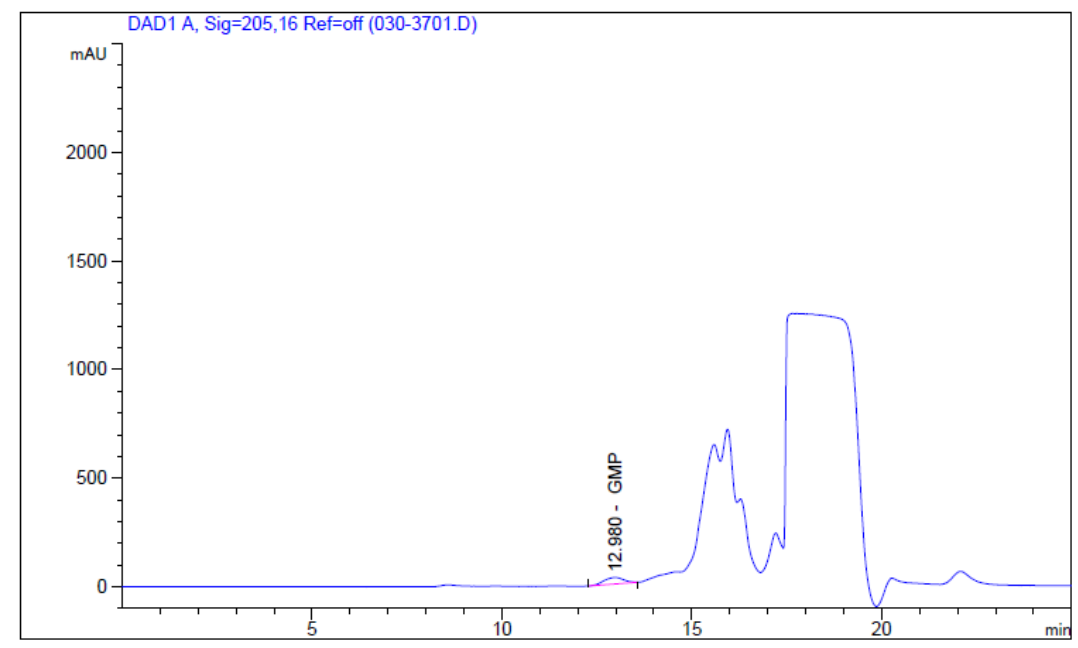

Figure 2. Typical chromatogram of sample determined by ultrasound precipitation method.

\subsection{Analysis by high performance liquid chromatography (HPLC-DAD)}

A diode array UV detector (DAD) liquid chromatograph LC Agilent technologies 1200 series capable of operating at $205 \mathrm{~nm}$, equipped with an autosampler HiP-ALS G1367B that injects between 20-100 $\mu \mathrm{L}$ were used. The size exclusion column (12) was a Zorbax GF-250 Analytical 9.4 x $250 \mathrm{~mm} 4-$ Micron column. The mobile phase was a buffer solution $\mathrm{pH} 6.0$ prepared by dissolution of $1.74 \mathrm{~g}$ of dipotassium phosphate $\left(\mathrm{K}_{2} \mathrm{HPO}_{4}\right), 12.37 \mathrm{~g}$ of potassium dihydrogen phosphate $\left(\mathrm{KH}_{2} \mathrm{PO}_{4}\right)$, and $21.41 \mathrm{~g}$ of anhydrous sodium sulfate $\left(\mathrm{Na}_{2} \mathrm{SO}_{4}\right)$, in $700 \mathrm{ml}$ of HPLC grade water, subsequently, the $\mathrm{pH}$ was adjusted to 6.0 using $0.1 \mathrm{M} \mathrm{K}_{2} \mathrm{HPO}_{4}$ completed to $1 \mathrm{~L}$ with type 1 water and finally the solution was filtered through a membrane of $0.45 \mu \mathrm{m}$. For the detection of the molecule, a diode array detector at a wavelength of $205 \mathrm{~nm}$ was used. Table 1 specifies the conditions runs.
Table 1. Size exclusion chromatography conditions

\begin{tabular}{lc}
\hline \multicolumn{1}{c}{ Condition } & Parameter \\
\hline Injection volumen & $50 \mu \mathrm{L}$ \\
Phase flow & $1 \mathrm{~mL} / \mathrm{min}$ \\
Oven temperature & $30^{\circ} \mathrm{C}$ \\
Holding time & $12,9 \pm 0,5$ minutes \\
Total analysis time & 30 minutes \\
\hline
\end{tabular}

Chemstation B 03.01 software was the tool used for data treatment and the integration parameters calculation.

\subsection{Method validation procedure}

Validation of the analytical method for the determination of casein glycomacropeptide (c-GMP) in milk by high-performance liquid chromatography (HPLC) was based on the recommendations of the ICH Topic Q2 (R1) Validation of Analytical Procedures: Text and Methodology (14). The criteria established to fulfill the different parameters evaluated were taken from the Official Methods of Analysis AOAC, which correspond to an RSD less than or equal to $5.3 \%$ for 
standards and samples prepared independently, for accuracy a percentage of recovery between 80 and $110 \%$. The parameters applied for the method validation were linearity, detection limit, quantification limit, instrument system precision, method precision, intermediate precision, truthfulness, robustness, working interval, and uncertainty.

\section{RESULTS AND DISCUSSION}

\subsection{Linearity}

A calibration curve was made with concentrations $0,10,30,50,70,100,200 \mathrm{mg} / \mathrm{L}$ of c-GMP (low range) and $100,700,1,000,2,000,3,000,5,000$ $\mathrm{mg} / \mathrm{L}$ of $\mathrm{c}-\mathrm{GMP}$ (high range) each point of the curve was evaluated with minimum two replicates per point. A linear coefficient of determination greater than or equal to 0.95 was presented for each of worked ranges. Thus, for the low range, $\mathrm{R}^{2}=0.99$ was obtained (Fig. 3), and for the high range, the value was $\mathrm{R}^{2}=0.98$ (Fig. 4). Therefore, it was shown that there is a high correlation between the concentration of c-GMP and the area of the chromatographic peak; it is stated that in this way, the calibration curve method was able to explain the instrumental response due to the concentration of c-GMP in the analyzed standards.

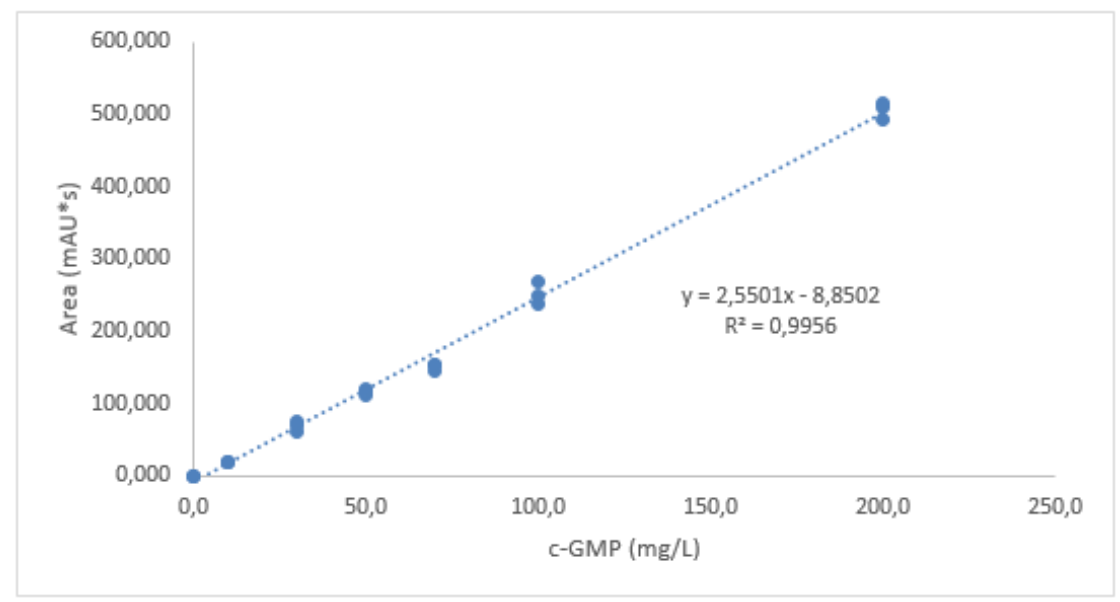

Figure 3. Linearity, equation of the line and correlation coefficient for low range.

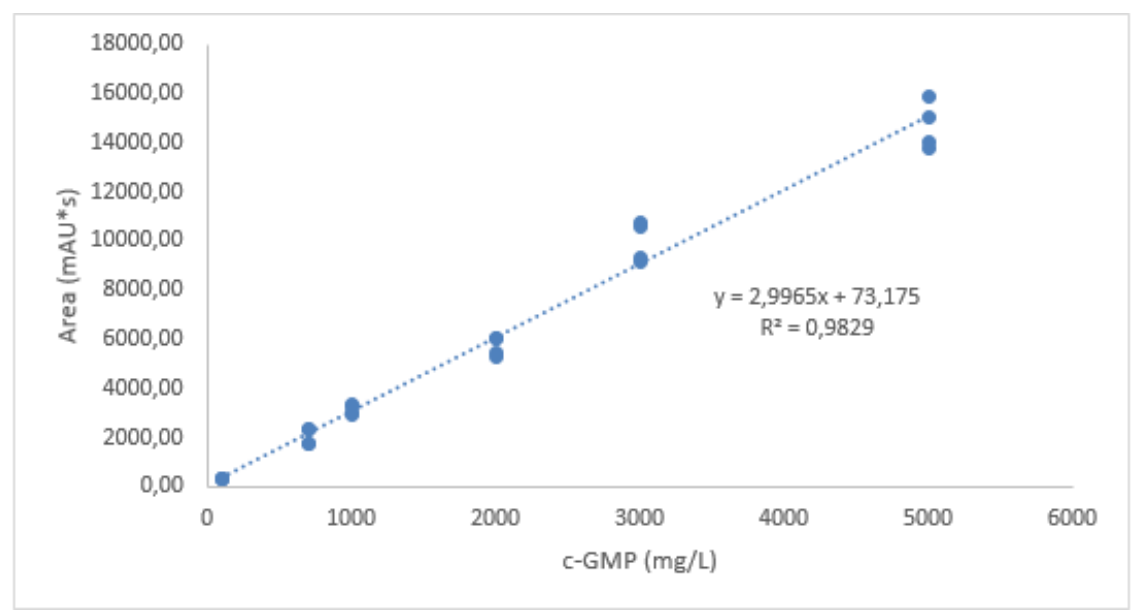

Figure 4. Linearity, equation of the line and correlation coefficient for high rank. 


\subsection{Limit of quantification (LOQ)}

The limit of quantification was established at a concentration of $20 \mathrm{mg} / \mathrm{L}$ because at $10 \mathrm{mg} / \mathrm{L}$ good reproducibility was not obtained (the\% RSD was 54.7\%). This value is lower than the "c-GMP-index", established to the level found in raw milk in Brazil (tolerance level for milk a value of $30 \mathrm{mg} / \mathrm{L}$ ) (2).

The $20 \mathrm{mg} / \mathrm{L}$ standard was prepared and injected ten times to obtain independent results under conditions of reproducibility (same analyst, same day), and the results evaluated to have adequate repeatability (RSD less than or equal to $5.3 \%$ and a recovery percentage between 80 and 110\%, according to the guideline reference AOAC 2019).

Obtained results from the limit of quantification, $\%$ recovery $103.2 \%$ and $\mathrm{RSD} 4.0 \%$, meet the acceptance criteria established by the method for (repeatability according to the guideline reference AOAC 2019 appendix F); therefore, 20.0 mg/L is established as LOO.

\subsection{Precision}

Three parameters determined the precision criteria: Instrumental system precision, method precision (analyzed by one analyst on the same day), and intermediate precision (evaluated under reproducibility conditions by two analysts on different days) (Table 2). Instrumental system precision was determined by analyzing three standards that included a concentration close to the low range of analysis $(60 \mathrm{mg} / \mathrm{L}$ mean value of the linearity curve used by T.M. Campos Motta et al. (2), medium standard (500 mg/L), and high standard $(4,000 \mathrm{mg} / \mathrm{L})$; the intermediate precision was determined in the three ranges and additionally a raw milk sample (matrix). All samples and standards were prepared, analyzed, and integrated independently by each analyst and analyzed by replicates.

In intermediate precision, the change of analyst was evaluated. We worked according to the model presented in ICH Q2 (R1) (14), where 6 replicates of samples and standards were analyzed. From the precision system and instrumental precision system and precision, results obtained demonstrate that the method is repeatable since the RSD values were less than $5.3 \%$ for the entire range and the evaluated sample. For intermediate precision, a statistical comparison was made using an Analysis of Variance (ANOVA) to assess whether there were significant differences when the analyst was changed. For each data group evaluated, it was obtained that the calculated $\mathrm{F}$ in all cases was lower than the critical $\mathrm{F}$; therefore, it is concluded that the used method is repeatable for both analysts (Table 2).

Table 2. Results of the intermediate precision exercise are expressed in $\mathrm{mg} / \mathrm{L}$ of c-GMP.

\begin{tabular}{ccccccccc}
\hline \multirow{2}{*}{ Parameter } & \multicolumn{2}{c}{ Low standard $\mathbf{6 0} \mathbf{~ m g / L}$} & \multicolumn{2}{c}{ Medium standard $\mathbf{5 0 0} \mathbf{~ m g / L}$} & \multicolumn{2}{c}{ High standard 4,000 $\mathbf{~ m g / L ~}$} & \multicolumn{2}{c}{ Sample } \\
\cline { 2 - 10 } & Analyst 1 & Analyst 2 & Analyst 1 & Analyst 2 & Analyst 1 & Analyst 2 & Analyst 1 & Analyst 2 \\
\hline- & 58.37 & 63.31 & 536.20 & 480.44 & $4,000.52$ & $4,214.97$ & 153.29 & 151.93 \\
- & 60.51 & 56.31 & 481.07 & 484.22 & $4,188.64$ & $3,937.48$ & 157.09 & 166.49 \\
- & 60.66 & 58.74 & 485.93 & 468.63 & $4,055.55$ & $4,092.76$ & 150.03 & 151.17 \\
- & 57.28 & 65.14 & 493.16 & 472.96 & $4,024.72$ & $3,934.81$ & 157.00 & 167.45 \\
- & 61.83 & 63.76 & 501.51 & 468.31 & $4,059.59$ & $3,949.70$ & 152.85 & 143.79 \\
- & 63.93 & 63.07 & 493.70 & 507.76 & $4,186.84$ & $3,969.42$ & 158.1 & 146.35 \\
\hline \%RSD & 3.95 & 5.54 & 3.95 & 3.09 & 2.00 & 2.83 & 2.04 & 6.54 \\
\hline
\end{tabular}

\subsection{Accuracy}

Accuracy testing was developed on the low standard $(60.0 \mathrm{mg} / \mathrm{L})$, the medium standard $(500 \mathrm{mg} / \mathrm{L})$, and the high standard $(4000 \mathrm{mg} / \mathrm{L})$ (Table 3). Six replicas were analyzed by each analyst who participated in the validation exercise, obtaining the accuracy analysis of 12 data analyzed. The accuracy was analyzed and evaluated as the percentage of recovery found in each replicate.

As an acceptance criterion, the recovery percentage should have been between 80 and $110 \%$. 
Table 3. Results of accuracy evaluation. For each data set a recovery percentage between 80 to $110 \%$ was obtained. The method used for the c-GMP test on the working gap had the accuracy required by the method under laboratory conditions. Compliance values obtained are in relative percentage (\%).

\begin{tabular}{|c|c|c|c|c|c|}
\hline \multicolumn{2}{|c|}{$\begin{array}{c}\text { LOW STANDARD } \\
60 \mathrm{mg} / \mathrm{L}\end{array}$} & \multicolumn{2}{|c|}{$\begin{array}{c}\text { MEDIUM STANDARD } \\
500 \mathrm{mg} / \mathrm{L}\end{array}$} & \multicolumn{2}{|c|}{$\begin{array}{c}\text { HIGH STANDARD } \\
4000 \mathrm{mg} / \mathrm{L}\end{array}$} \\
\hline RESULT (mg/L) & Recovery (\%) & RESULT (mg/L) & Recovery (\%) & RESULT (mg/L) & Recovery (\%) \\
\hline 58.37 & $97.3 \%$ & 536.20 & $107.2 \%$ & $4,000.52$ & $100.0 \%$ \\
\hline 60.51 & $100.9 \%$ & 481.07 & $96.2 \%$ & $4,188.64$ & $104.7 \%$ \\
\hline 60.66 & $101.1 \%$ & 485.93 & $97.2 \%$ & $4,055.55$ & $101.4 \%$ \\
\hline 57.28 & $95.5 \%$ & 493.16 & $98.6 \%$ & $4,024.72$ & $100.6 \%$ \\
\hline 61.83 & $103.1 \%$ & 501.51 & $100.3 \%$ & $4,059.59$ & $101.5 \%$ \\
\hline 63.93 & $106.6 \%$ & 493.70 & $98.7 \%$ & $4,186.84$ & $104.7 \%$ \\
\hline 63.31 & $105.5 \%$ & 480.44 & $96.1 \%$ & $4,214.97$ & $105.4 \%$ \\
\hline 56.31 & $93.8 \%$ & 484.22 & $96.8 \%$ & $3,937.48$ & $98.4 \%$ \\
\hline 58.74 & $97.9 \%$ & 468.63 & $93.7 \%$ & $4,092.76$ & $102.3 \%$ \\
\hline 65.14 & $108.6 \%$ & 472.96 & $94.6 \%$ & $3,934.81$ & $98.4 \%$ \\
\hline 63.76 & $106.3 \%$ & 468.31 & $93.7 \%$ & $3,949.70$ & $98.7 \%$ \\
\hline 63.07 & $105.1 \%$ & 507.76 & $101.6 \%$ & $3,969.42$ & $99.2 \%$ \\
\hline
\end{tabular}

According to the obtained results (Table 3), the recovery percentage was within the acceptance criteria for the concentrations evaluated. Therefore, the test method for determining c-GMP in raw milk gives accurate results in the entire range worked.

\subsection{Robustness}

A comparison among the obtained results in milk with and without a preservative was made to evaluate the technique's robustness. The preservative used was $0.2 \%$ hydrogen peroxide $\left(0.67 \mathrm{~mL}\right.$ of $30 \% \mathrm{H}_{2} \mathrm{O}_{2}$ per $100 \mathrm{~mL}$ of milk). An $\mathrm{F}$ test was performed to estimate whether the variances of the curves in the two different conditions are homogeneous, and subsequently, a t-student test was performed to evaluate whether there are significant differences in the obtained curves.

In the $\mathrm{F}$ test applied to the curves was obtained, a $F_{\text {cal }}(0,52)<F_{\text {cri }}(2,47)$; therefore, the variance of the two slopes is homogeneous. A t-student test was performed to establish a significant difference between the two treatments (with and without the addition of a preservative). It was found that $t_{\text {cal }}(1,49)$ $<t_{c r i}(2,02)$; therefore, the obtained curves (with addition and without preservative addition) are not significantly different.

\subsection{Work interval}

The interval is defined between the limit of quantification found experimentally in the validation exercise, and the highest sample or standard worked during the process.

According to the obtained results, it is established that the working range for the c-GMP assay, taking into account standard purity used (76\%) in liquid milk, is from $15.2 \mathrm{mg} / \mathrm{L}$ to $3,800 \mathrm{mg} / \mathrm{L}$.

\subsection{Uncertainty}

The uncertainty was estimated following the guidelines of the guide for the expression of measurement uncertainty - GUM. The associated uncertainty of the calibration curve that included the residual analysis of the curve obtained experimentally and the reference material was independently calculated (Fig. 5) $\left(\mu_{\text {combined }}=2,0725\right)$, additional values calculated were uncertainty associated with sample preparation $\left(\mu_{\text {combined }}=0,00014057\right.$ ) and uncertainty from validation data (Instrumental repeatability $\mu_{\text {combined }}=0,012$, intermediate precision $\left.\mu_{\text {combined }}=0,0116\right)$. The expanded uncertainty calculated considering a confidence level of $95 \%$ and a coverage factor of $K=2$ was $4.1 \mathrm{mg} / \mathrm{L}$ of c-GMP. 


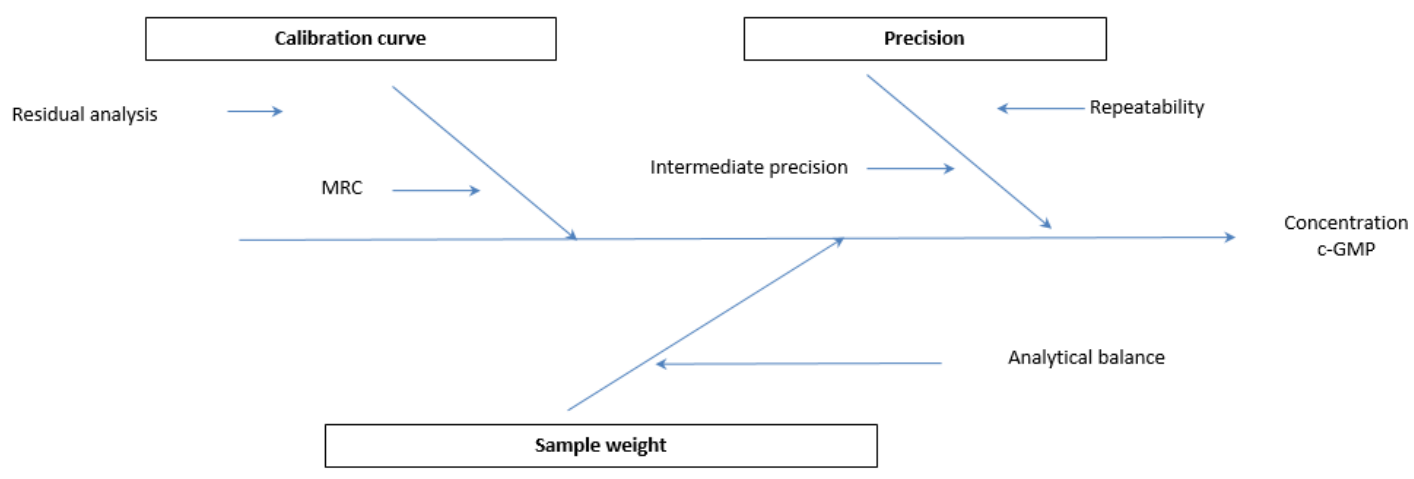

Figure 5. Identification of sources of uncertainty through the cause - effect diagram.

\section{CONCLUSIONS}

The method for determining c-GMP in raw milk was reviewed and validated using high-efficiency liquid chromatography with a UV detector and size exclusion column. The results of the validation of the method showed that the linearity criteria (R2>0.95) are suitable for the high and low range, instrument system precision, method precision (\% RSD <5.3\%), limit of quantification, and accuracy (percentage of recovery between $80-110 \%$ ).

This method can be used in raw milk, without any sanitization or stabilizer addition; hence, it is helpful for monitoring and control throughout the production chain: supplier selection, monitoring, and verification.

c-GMP quantification employing high-efficiency liquid chromatography by size exclusion is an appropriate methodology for industries due to its short analysis time, easy sample and standards preparation, adequate instrumental response, as well as the conditions of precision and reproducibility.

The revised and validated chromatography technique becomes a technique that is aligned with official control methodologies in countries like Brazil. This methodology quantifies c-GMP as an indicator of whey adulteration in concentrations between $15.2 \mathrm{mg} / \mathrm{L}$ to $3,800 \mathrm{mg} / \mathrm{L}$.

The results of the validation exercise demonstrated that under the specific conditions of the laboratory, it behaves according to the characteristics for the intended use and responds to the needs of c-GMP determination utilizing high-performance liquid chromatography with a size exclusion column.

\section{REFERENCES}

1. Aparecida de Carvalho BM, Millena de Carvalho L, Reis Coimbra JS, Minim LA, Barcello E de S, Silva Júnior WF, et al. Rapid detection of whey in milk powder samples by spectrophotometric. Food Chem. 2015;174(November):1-7. DOI: https://doi.org/10.1016/j. foodchem.2014.11.003

2. Motta TMC, Hoff RB, Barreto F, Andrade RBS, Lorenzini DM, Meneghini LZ, et al. Detection and confirmation of milk adulteration with cheese whey using proteomic-like sample preparation and liquid chromatography-electrospray-tandem mass spectrometry analysis. Talanta [Internet]. 2014;120:498-505. DOI: http://dx.doi.org/10.1016/j.talanta.2013.11.093

3. Ministry of Health and Social Protection. Decreto Numero 616 de 2006. Minist Heal Soc Prot [Internet]. 2006;32. Available from: https://www.ica.gov.co/getattachment/15425e0f-81fb-4111-b21563e61e9e9130/2006D616.aspx

4. de Oliveira Mendes T, Manzolli Rodrigues BV, Simas Porto BL, Alves da Rocha R, de Oliveira MAL, de Castro FK, et al. Raman Spectroscopy as a fast tool for whey quantification in raw milk. Vib Spectrosc. 2020;111(September). DOI: http://doi.org/10.1016/j. vibspec. 2020.103150

5. Evelin Rojas V, Emiro Valbuena C., Gabriel Torres F., Aiza García de H., María Piñero G. y Luz Mila Galindo A. Aislamiento y rendimiento del GMP mediante precipitación de lactosuero con ácido tricloroacético. Rev Científica. 2009;19(Septiembre):1-11. Available from: http://ve.scielo.org/scielo.php?script=sci_arttex t\&pid $=$ S0798-22592009000300013

6. Sharma R. Whey proteins in functional foods. Whey Proteins: From Milk to Medicine. Edited by Hilton C Deeth, Nidhi Bansal. Academic Press 2018. p. 637-63.

7. Sing Yadav JS, Yan S, Pilli S, Kumar L, Tyagi R., Surampalli R. Cheese whey: A pontential resource to transform into bioprotein, functional/nutritional proteins and bioactive peptides. Biotechnol Adv. 2015;33(July):756-74. DOI: http://dx.doi.org/10.1016/j. biotechadv.2015.07.002

8. Sharma N, Sharma R, Rajput YS, Mann B, Gandhi K. Distinction between glycomacropeptide and $\beta$-lactoglobulin with 'stains all' dye on tricine SDS-PAGE gels. Food Chem [Internet]. 2021;340(January 2020):127923. DOI: https://doi.org/10.1016/j. foodchem.2020.127923

9. Huth PJ, Layman DK, Brown PH. The Emerging Role of Dairy Proteins and Bioactive Peptides in Nutrition and Health: Foreword. J Nutr. 2004;134(4):996-1002. 
10. Oliemanr C, Van Den Bedem2 JW. A sensitive HPLC method of detecting and estimating rennet whey total solids in skim milk powder. Nerh itl Ilk Daírr J. 1983.

11. Patricio E, Llerena M, García-romero A, Mayorga-llerena E. suero dulce con proteasas de bacterias psicrótrofas e identificación de leche ... Correlación de glicomacropéptido de lacto suero dulce con proteasas de bacterias psicrótrofas e identificación de leche adulterada. X Congr Cienc Y Tecnol Espe 2015 [Internet]. 2015;(June):267-70. Available from: http://journal.espe.edu.ec/ index.php/cienciaytecnologia/article/view/58

12. Poa MET, Agropecu N, Emiss OA, Met E. Determinação de Índice de CMP por SEC Determinação de Índice de CMP por SEC. Brasil:
Laboratório Nacional Agropecuário - LANAGRO/RS. Laboratório de Produtos de Origem Animal; 2014. p. 1-11. Available from: https://docplayer.com.br/28733684-Determinacao-de-indice-decmp-por-sec.html

13. Liebenberg N, Jensen E, Larsen ER, Kousholt BS, Pereira VS, Fischer CW, et al. A Preclinical Study of Casein Glycomacropeptide as a Dietary Intervention for Acute Mania. Int J Neuropsychopharmacol. 2018;21(5):473-84. DOI: https://doi.org/10.1093/ijnp/pyy012

14. Guy RC. International Conference on Harmonisation. Encycl Toxicol Third Ed. 2014;2(June 1995):1070-2. 